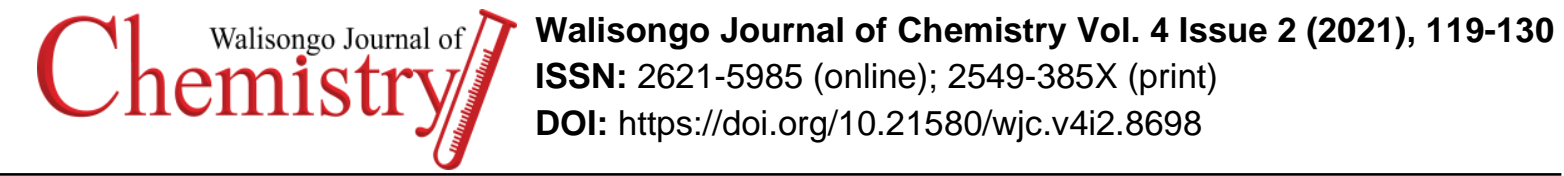

\section{Validation of Pesticides Multi-Residual Testing Method on Nutmeg by Using UPLC-MS/MS}

\author{
Bayu Refindra Fitriadi \\ Balai Besar Perbenihan dan Proteksi Tanaman Perkebunan (BBPPTP) Surabaya \\ Jl. Raya Mojoagung No. 52 Jombang Jawa Timur Indonesia \\ E-mail: bayurefindra@pertanian.go.id
}

Received: 24 July 2021; Accepted: 5 October 2021; Published: 15 December 2021

\begin{abstract}
The use of pesticides in nutmeg still leaves an accumulation of pesticide residues that can endanger human health and damage the ecological balance. In addition, nutmeg with high pesticide residue content will be rejected by nutmeg export destination countries. This research was conducted to validate the method of testing pesticide residues of carbaryl, carbofuran, acetate, and dimethoate on nutmeg. This pesticide residue test uses the QuEChERS (Quick, Easy, Cheap, Effective, Rugged, and Safe) optimization method and is analyzed using UPLC-MS/MS (Ultra Performance Liquid ChromatographyTandem Mass Spectrometry). This method meets the validation requirements according to SANTE/12682/2019. The limit of quantification (LOQ) of the analyte is below the Maximum Residue Limit (MRL) set by the European Union through Regulation (EC) No. 396/2005.
\end{abstract}

Keywords: pesticide residue; UPLC-MS/MS; nutmeg; QuEChERS

\section{Introduction}

Indonesian spice commodities contribute quite a large amount of foreign exchange for the country. One of which is nutmeg as the main commodity of spices in Indonesia. Indonesia as the world's largest producer of nutmeg supplies about $66-77 \%$ of the world market. Smallholders especially in five provinces, namely North Maluku, Maluku, Aceh, North Sulawesi, and West Papua, cultivate most of the nutmeg plantations in Indonesia (99.78\%). Based on statistical data from the Directorate General of Plantations (2019), the area of nutmeg plantations in Indonesia reaches 229,139 hectares with a production of 44,100 tons and a productivity level of $543 \mathrm{~kg} / \mathrm{ha}$. To increase the productivity of nutmeg, pest and disease control are important. In addition, the use of pesticides is one of the factors in controlling these pests. However, due to the limited knowledge of farmers, the use of pesticides is often not controlled. Carbofuran pesticides are one of the pesticides used by nutmeg farmers to control stem borer pests (Batocera $s p$ ) and cancer stem (Pesireron et al., 2019). In addition, pesticides that are often used by nutmeg farmers include insecticides from the organophosphate group such as acetate and dimethoate as well as carbaryl to treat termites and fungicides to treat fruit breakage or white split disease caused by the fungus Coryneum myristicae. 
The uncontrolled use of carbamate and organophosphate pesticides in controlling pests and diseases can leave large amounts of residue on nutmeg. This residue can be harmful to humans. Therefore, the European Union through Regulation (EC) No. 396/2005 has set the Maximum Residue Limit (MRL) of pesticides on nutmeg, namely $0.05 \mathrm{mg} / \mathrm{kg}$ for carbaryl; $0.05 \mathrm{mg} / \mathrm{kg}$ for carbofuran; $0.2 \mathrm{mg} / \mathrm{kg}$ for acetate and $5 \mathrm{mg} / \mathrm{kg}$ for dimethoate.

Therefore, it needs sensitive and selective methods of testing carbamate and organophosphate pesticide residues on nutmeg. One of them is the fast, easy, cheap, effective, sturdy, and safe sample preparation method or QuEChERS (Quick, Easy, Cheap, Effective, Rugged, and Safe). It was introduced by Anastassiades, et al., (2003) and has been used in the analysis of multiple pesticide residues on various sample matrices. It has many advantages such as simple, few stages of analysis and effective in the clean-up process. It is also environmentally friendly because it only requires a small amount of organic solvent, which is in line with the current trend of "green analytical chemistry" (Zhang, et al., 2016; Biziuk, M. and Stocka, J., 2015). The QuEChERS method has been widely used to detect pesticide residues in fruits (Jahanmard, E., Ansari, F., and Feizi, M., 2016; Machado, et al., 2017; Paz, et al., 2017), milk (Ferronato, et al., 2018), and vegetables (Boes et al l., 2015). However, spice commodities such as nutmeg have unique matrix characteristics (SANTE, 2020). It is necessary to develop and optimize the QuEChERS method to obtain optimal test results (Fitriadi, B.R., and Putri, A.C., 2016). The European Union through the British Standard Method EN 15662:2018 (British Standard, 2018), in general, has carried out the development of the QuEChERS method for testing on spice commodities. However, this method still needs to be validated to convince the laboratory of this method.

Based on the SNI ISO/IEC 17025:2017 document (National Standardization Agency, 2017), method validation is one of the requirements listed in clause 7.2 , namely the laboratory must record all the results obtained, the validation procedure used, and a statement that the method used is correct. In testing pesticide residues, several guidelines can be used as a basis for determining method validation in pesticide residue analysis. One of them is the guide from SANTE 12682/2019 (SANTE, 2019). This guide is explained in full and in detail and is easy to apply for method validation. The main parameters as a reference in method validation according to the SANTE document 12682/2019 are sensitivity/linearity, matrix effect, ion ratio, retention time, the limit of quantification (LOQ), specificity, accuracy / repeatability, precision / reproducibility, and trueness. Other validation guidelines can refer to documents issued by Eurochem (Eurachem, 1998).

Method validation is very necessary for both developed and optimized methods because the proposed method must be linear, accurate, and repeatable so that it can be widely used in commercial laboratories to analyze pesticide residues for domestic and export purposes (Das, et al., 2020; Koçyiğit, et al., 2020).

Research conducted by Boneva, et al. (2021) has successfully validated the development of the organophosphate residue method but still refers to the SANTE/11945/2015 document. Ekaputri (2013) also researched the validation of the pesticide residue method, but the validation parameters of the method used were only linearity, precision, accuracy, and determination limits so that they still did not meet the acceptability limits according to the SANTE document.

In this study, we report the results of the validation of the multi-residual testing method for carbamate and organophosphate pesticides on nutmeg by referring to the SANTE $12682 / 2019$ document that will be submitted for accreditation by KAN. The mass spectrometry tandem liquid chromatography method used is a method that has been developed for a long time, has been applied to various samples, has advantages in terms of short execution time, can be used for the 
analysis of several compounds at once, and has a very low detection limit (parts per billions).

\section{Research method}

\section{Apparatus and Reagents}

The devices used in this study were blender (KMix, Kenwood, USA), vortex (Biosan, Latvia), refrigerator $-20^{\circ} \mathrm{C}$ (Samsung, South Korea), centrifuge (MX-307, Tomy, Japan), micropipette (Eppendorf, USA). ), water purifier (Arium, Sartorius, Germany), Shaker (Benchmark, USA), liquid chromatographytandem mass spectrometry UPLC-MS/MS (Xevo TQD, Waters, USA), and column C-18 (Waters, USA).

The reagents used in this study included acetonitrile (hyper grade for LC-MS, E. Merck Germany), methanol (hyper grade for LC-MS, E. Merck Germany), Ammonium formate (99.0\%, Sigma Aldrich, USA), EN QuEChERS extraction kit (4 g MgSO4, $1 \mathrm{~g} \mathrm{NaCl}, 0.5 \mathrm{~g}$ trisodium citrate dehydrate, $0.5 \mathrm{~g}$ disodium hydrogen citrate sesquihydrate, Waters, USA), EN QuEChERS dSPE (900 mg MgSO4, 150 mg PSA, Waters, USA), carbaryl standard (99.5\%, Chem Service, USA), carbofuran standard $(99.5 \%$, Chem Service, USA), acephate standard (99.5\%, Chem Service, USA), dimethoate standard (98.3\%, Chem Service, USA).

\section{Procedures}

\section{Sample preparation}

Nutmeg sample preparation was carried out by using the QuEChERS method. Mix the sample until homogeneous then puree using a blender. Weigh 2 grams of the sample and then put it into a $50 \mathrm{~mL}$ tube. Add $10 \mathrm{~mL}$ of distilled water and shake for 1 minute, then let stand 30 minutes. Add $10 \mathrm{~mL}$ of acetonitrile and shake again for 1 minute, then shaker at $500 \mathrm{rpm}$ for 15 minutes. Add EN QuEChERS Extraction and Ceramic homogenizer then shake with a shaker at $2500 \mathrm{rpm}$ for 2 minutes. Centrifuge at 4500 rpm for 5 minutes.

Put $6 \mathrm{~mL}$ of the extraction into a $15 \mathrm{~mL}$ dSPE, and then shake with a shaker at a speed of $2,500 \mathrm{rpm}$ for 1 minute. Centrifuge at 14,000 rpm for 3 minutes. Take $1 \mathrm{~mL}$ of each solution using a syringe and filter the solution with a 0.2 $m$ filter into the LC vial. Standard series were made with different concentrations from six concentration points, namely $5 \mathrm{ng} / \mathrm{mL}, 10$ $\mathrm{ng} / \mathrm{mL}, 30 \mathrm{ng} / \mathrm{mL}, 50 \mathrm{ng} / \mathrm{mL}, 70 \mathrm{ng} / \mathrm{mL}$, and 100 $\mathrm{ng} / \mathrm{mL}$. Dilution using acetonitrile solvent.

\section{Sample analysis}

Previously, the mobile phase was prepared for mass spectrometry tandem liquid chromatography for three compositions. They were composition 1 (mobile phase A Water: Methanol (98:2) + 0.1\% Formic Acid and mobile phase B Methanol $+0.1 \%$ Formic Acid); composition 2 (mobile phase A: Water + Ammonium formate $10 \mathrm{mM}$, mobile phase B Methanol + Ammonium formate $10 \mathrm{mM}$ ); composition 3 (mobile phase A contained $5 \mathrm{mM}$ ammonium formate in $20 \%$ methanol and mobile phase $\mathrm{B}$ contained $5 \mathrm{mM}$ ammonium formate in $90 \%$ methanol). The column used was BEH C18, 2.1 x $100 \mathrm{~mm}, 1.7 \mu \mathrm{m}$, column temperature $40^{\circ} \mathrm{C}$, full loop injection mode, injection volume $3 \mu \mathrm{L}$, and sample temperature $10^{\circ} \mathrm{C}$. MS conditions with positive Electrospray Ionization $\left(\mathrm{ESI}^{+}\right)$mode, capillary voltage $1 \mathrm{kV}$, Nitrogen desolvation $1000 \mathrm{~L} /$ hour $500^{\circ} \mathrm{C}$, Cone of Nitrogen $5 \mathrm{~L} /$ hour, Souce ion temperature $150^{\circ} \mathrm{C}$, Acquisition MRM, Collision of Argon 3.5 mBar. Then the first tuning is done for each analyte. After that, all variations of the concentration of the standard solution were injected into the UPLC-MS/MS apparatus and the area of the peak area was recorded. In addition, the prepared samples were also injected.

\section{Method Validation}

Method validation was carried out based on the SANTE/12682/2019 document regarding the Guidance Document on Analytical Quality Control and Method Validation Procedures for Pesticide Residues and Analysis in Food and Feed. For sensitivity/linearity, it is calculated by making at least 5 standard series concentration points then measuring the 
response of each standard series and calculating the value of $\%$ residual standard series (deviation from the recalculated concentration). The matrix effect parameter is determined by calculating the difference in the average response of the standard in the matrix and the solvent. If the difference in response is $> \pm 20 \%$, the analysis should be carried out with the standard procedure in the matrix.

The parameter of ion ratio is determined by processing confirmatory and quantification ion data from the standard. The sample ion ratio must be within the range of $\pm 30 \%$ of the average sample of ion ratio value in one sequence. The retention time parameter was calculated by comparing the average retention time of the analyte in the solvent and the matrix. The determination limit parameter or LOQ is carried out by preparing five blank sample solutions with standard fortification at the target concentration of the determination limit, then calculating the average, standard deviation (SD), percent RSD, and percent recovery.

The specificity parameter was replicated five times on each reagent blank and sample blank based on the preparation procedure. If there is a target peak, integrate it and calculate the concentration. The analyte concentration should be $<30 \%$ of the determination limit (LOQ). The precision and trueness parameters were made by preparing five sample solutions with standard fortification and then calculating the average sample content, standard deviation, and percent relative standard deviation.

\section{Results and Discussion}

Nutmeg farmers often used carbaryl, carbofuran, acephate, and dimethoate to overcome pest attacks on nutmeg plants. Nutmeg is safe for human consumption if the pesticide residue is less than the Maximum Residue Limit (MRL) set by the government or authorized institution. European Union through Regulation (EC) No. 396/2005 has set the Maximum Residue Limit (MRL) of pesticides on nutmeg, namely $0.05 \mathrm{mg} / \mathrm{kg}$ for carbaryl; 0.05 $\mathrm{mg} / \mathrm{kg}$ for carbofuran; $0.2 \mathrm{mg} / \mathrm{kg}$ for acetate and $5 \mathrm{mg} / \mathrm{kg}$ for dimethoate.

To ensure the quality of the nutmeg samples used in this study, nutmeg samples were taken from one of the nutmeg exporters in East Java Province based on the solid sampling rules of SNI-19-0428-1998. The samples were stored in thick plastic bags with labels and seals to be immediately brought to the laboratory and stored in the sample storage area.

Validation of this method was carried out at the Pesticide Analysis Laboratory of the Plantation, Seed, and Protection Center of Surabaya. The test method refers to the document BS EN 15662:2018 about "Multimethod for the determination of pesticide residues using GC- and LC-based analysis following acetonitrile extraction/partitioning and clean-up by dispersive SPE - Modular QuEChERS-method" issued by the European Commission with some adjustments and improvements.

\section{UPLC-MS/MS Optimization}

The important thing that needs to be considered in the analysis using the UPLCMS/MS tool is the selection of the right mobile phase. In this study, optimization of several mobile phase compositions was carried out which gave the best sensitivity for the analysis of carbamates and organophosphates in nutmeg. This is because the nutmeg matrix has unique characteristics and the types of carbamate and organophosphate pesticides have a broad spectrum. It is unique because nutmeg contains a lot of lignin, stearin, essential oil (myristicin), and starch (Mancha A., and Fuentes J., 2008) which have the potential to affect the chromatogram in the analysis by using UPLC-MS/MS so it needs an appropriate preparation method.

The composition of the mobile phase used for optimization in this study is listed in table 1. From the three variations of the mobile phase composition, composition I obtained a short retention time of analyte peaks and relatively small analyte peaks. While composition II 
produced analyte peaks with long retention times and small peak sensitivity. Composition III showed better sensitivity results for carbaryl, carbofuran, acetate, and dimethoate pesticides in the nutmeg matrix compared to other compositions, although the retention time was quite long but still within normal limits (less than 5 minutes). Henceforth, the mobile phase composition III was used for analysis in this study.

Table 1. Variation of the mobile phase composition

Another factor that needs to be

\begin{tabular}{ccc}
\hline Composition & $\begin{array}{c}\text { Mobile Phase } \\
\text { A }\end{array}$ & $\begin{array}{c}\text { Mobile Phase } \\
\text { B }\end{array}$ \\
\hline \multirow{4}{*}{ I } & Water: & Methanol + \\
& Methanol & $\begin{array}{c}0.1 \% \text { Formic } \\
(98: 2)+0.1 \%\end{array}$ \\
& Formic Acid & Acid \\
\hline \multirow{3}{*}{ II } & Water + & Methanol + \\
& Ammonium & Ammonium \\
& formate 10 & formate 10 \\
mM & mM \\
\hline \multirow{3}{*}{ III } & $5 \mathrm{mM}$ & $5 \mathrm{mM}$ \\
& ammonium & ammonium \\
& formate in & formate in \\
& $20 \%$ methanol & $90 \%$ methanol \\
\hline
\end{tabular}

considered in optimizing the tool is the parameter for quantification and confirmation of each analyte, namely the value of cone voltage and collision energy. This value is obtained from the tuning of each analyte on the UPLC-MS/MS tool. This parameter is important in determining the sensitivity of the precursor ions or daughter mass of each analyte to be used as a determinant of quantification and confirmation of the analyte. After tuning each analyte, the data obtained were listed in Table 2.

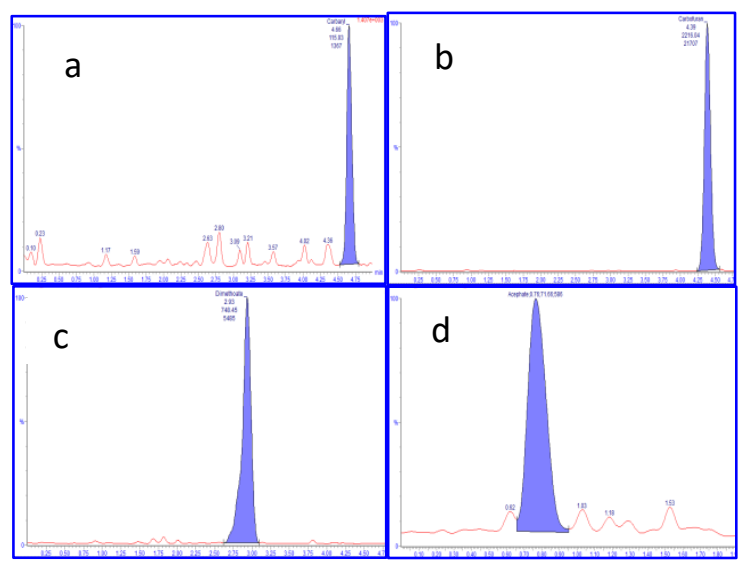

Figure 1. Chromatogram of analyte on nutmeg matrix with a concentration of 0.075 $\mathrm{mg} / \mathrm{kg}$; a. carbaryl. b. carbofuran. c. dimethoate. d. acephate

From Figure 1, there was information that at a small concentration level of 0.075 $\mathrm{mg} / \mathrm{kg}$ on carbaryl. carbofuran. dimethoate. and acetate is still obtained quite high with a good peak shape. This indicates that the sensitivity of the tool is still high. 
Table 2. The Parameters of UPLC-MS/MS

\begin{tabular}{ccccccc}
\hline Analyte & $\begin{array}{c}\text { Retention } \\
\text { Time } \\
\text { (Minutes) }\end{array}$ & $\begin{array}{c}\text { Parent } \\
\text { mass }\end{array}$ & $\begin{array}{c}\text { Daughter } \\
\text { mass }\end{array}$ & $\begin{array}{c}\text { Cone } \\
\text { voltage }\end{array}$ & $\begin{array}{c}\text { Collision } \\
\text { Energy }\end{array}$ & $\begin{array}{c}\text { Ion } \\
\text { Mode }\end{array}$ \\
\hline \multirow{2}{*}{ Carbaryl } & \multirow{2}{*}{4.66} & \multirow{2}{*}{202.22} & 143.13 & 24 & 24 & ESI+ \\
& & & 127.08 & 24 & 10 & ESI+ \\
\hline \multirow{2}{*}{ Carbofuran } & \multirow{2}{*}{4.39} & \multirow{2}{*}{222.20} & 163.13 & 30 & 24 & ESI+ \\
& \multirow{2}{*}{ Acephat } & \multirow{2}{*}{0.76} & 123.02 & 30 & 12 & ESI+ \\
\hline \multirow{2}{*}{ Dimethoate } & \multirow{2}{*}{2.93} & \multirow{2}{*}{230.10} & 125.10 & 25 & 18 & ESI+ \\
& & & 145.00 & 25 & 8 & ESI+ \\
\hline
\end{tabular}

\section{Validation and Development Method}

Determination of pesticide residues in nutmeg in this study consisted of two stages. They are the extraction stage and the clean-up stage. The extraction stage intends to separate the target analyte compound (pesticide) from the nutmeg matrix by using an appropriate solvent. While the cleanup stage intends to separate other organic compounds that are still carried in the acetonitrile solvent (Fitriadi, B.R., and Putri, A.C., 2019).

Proper extraction and clean-up methods are needed to produce good recoveries and chromatograms free from impurity peaks. In the nutmeg study, the most important thing is to remove the essential oil and other organic compounds from the nutmeg without removing the pesticides contained in the nutmeg matrix. This is because of a very complex nutmeg matrix that can interfere with the chromatogram results. The matrix peaks can affect the chromatogram peaks of the active pesticide ingredients so that test results will be biased. One of the keys to overcoming is good preparation at the beginning of the test so that the preparation solution is relatively clean from impurities. Homogenization of the nutmeg sample by crushing it to a small size aims to facilitate the interaction of the sample with the extracting material. It will optimize the analysis of pesticide residues contained in the sample.
The samples used in this study were 2 grams of nutmeg. The samples used were adjusted to the level of water in the nutmeg itself and its characteristics. In addition, this small amount was to reduce the interference of organic compounds and nutmeg essential oil on the chromatogram.

The addition of water to the nutmeg sample is a crucial thing in the extraction process because it has relatively little water content. According to Dinar, L., Suyantohadi, A., and Fajar, M.A. (2013), the moisture content in dry nutmeg seeds is around 8-11\%. In addition, the addition of polar water can hydrate the sample, weaken the interaction of pesticides with components of the nutmeg matrix, and help efficiency in the extraction process (solvent penetration into the nutmeg matrix during extraction). In this method, the researcher used acetonitrile as a solvent because it has a wide range of polarity for pesticide residues compared to other solvents such as acetone and ethyl acetate (Mastovska, K.and Lehotay, S.J., 2004). Almost $90 \%$ of pesticides are non-polar and can dissolve in acetonitrile solvents. Therefore, it is expected that the use of this solvent can separate the pesticide compounds in the sample.

\section{4}


In addition, the different solubility properties of acetonitrile solvent with water can facilitate separation with water during the extraction process. On the other hand, the Electrospray Ionization (ESI) mode on the UPLC-MS/MS device used in this study requires a polar solvent with good volatility, low viscosity value, low surface tension, and high ionic strength. So acetonitrile is used as an organic solvent (Harmoko. Kartasasmita. RE., and Tresnawati. A., 2015). Research from Dutta. D., Hingmire, S., and Banerjee, K., (2020) stated that the use of acetonitrile solvent resulted in a better recovery value (70-120\%) compared to the use of ethyl acetate solvent that gave a higher recovery value than $120 \%$.

Pesticide extraction from nutmeg samples used $\mathrm{MgSO}_{4}$ and $\mathrm{NaCl}$ to separate water from the samples. To ensure extraction efficiency and analyte stability, this extraction was carried out at room with a temperature of $24.4^{\circ} \mathrm{C}$ and $45 \%$ humidity in the morning at 09.00-12.00. In addition, trisodium citrate dehydrate and disodium hydrogen citrate sesquihydrate were used as citrate buffer to accelerate the separation of water from samples and acetonitrile solvents containing pesticides. This optimization will improve the separation of impurities better. Primary Secondary Amine (PSA) serves to separate organic acids, polar pigments, some sugars, and fatty acids from the solvent. While $\mathrm{MgSO}_{4}$ serves to remove water that is still left in the solution.

The next preparation stage is the clean-up stage. This stage is very important to eliminate impurities from the nutmeg matrix left from the extraction stage. The presence of a nutmeg matrix will interfere with the analysis of the analyte. This is in line with research from Dutta, D., Hingmire, S., dan Banerjee, K., (2020) which stated that some pesticide analytes that are not cleaned up give a high recovery value ( $>140 \%)$.

The developed test method was validated then based on the SANTE/12682/2019 document with the parameter criteria generated according to table 3 below.

Table 3. Parameter Validation Method according to SANTE/12682/2019

\begin{tabular}{|c|c|c|c|c|c|}
\hline Parameters & Crabaryl & Carbofuran & Acephate & Dimethoate & Terms* \\
\hline $\begin{array}{l}\text { Sensitivity / } \\
\text { Linearity } \\
\text { (\% Residual) } \\
\end{array}$ & $\begin{array}{c}-3.9 \mathrm{~s} / \mathrm{d} \\
2.0 \%\end{array}$ & $-9.5 \mathrm{~s} / \mathrm{d} 18.5 \%$ & $-9.9 \mathrm{~s} / \mathrm{d} 4.7 \%$ & $-4.5 \mathrm{~s} / \mathrm{d} 15.3 \%$ & $< \pm 20 \%$ \\
\hline Matrix Effect & $13.87 \%$ & $15.89 \%$ & $-25.84 \%$ & $-21.96 \%$ & \\
\hline Ion Ratio & $75-125 \%$ & $80-120 \%$ & $75-110 \%$ & $75-125 \%$ & $70-130 \%$ \\
\hline Retention time & -0.012 & -0.014 & 0.012 & -0.006 & \pm 0.100 \\
\hline LOQ (mg/kg) & 0.019 & 0.042 & 0.085 & 0.068 & $<$ MRL $^{* *}$ \\
\hline Specificity & $0 \%$ & $0 \%$ & $0 \%$ & $1.98 \%$ & $<30 \%$ LOQ \\
\hline $\begin{array}{c}\text { Accuracy / } \\
\text { Repeatability } \\
\left(\mathrm{RSD}_{\mathrm{wR}}, \mathrm{n}=5\right) \\
\end{array}$ & $8.95 \%$ & $12.17 \%$ & $3.85 \%$ & $8.55 \%$ & $< \pm 20 \%$ \\
\hline $\begin{array}{c}\text { Precision / } \\
\text { Reproducibility } \\
\text { (RSD }{ }_{\text {wR. }} \mathrm{n}=5 \text { ) }\end{array}$ & $8.43 \%$ & $11.47 \%$ & $3.63 \%$ & $8.06 \%$ & $< \pm 20 \%$ \\
\hline $\begin{array}{c}\text { Trueness } \\
\text { (\% recovery, } \mathrm{n}=5 \text { ) } \\
\text { Spike } 0.075 \mathrm{mg} / \mathrm{kg} \\
\text { Spike } 0.350 \mathrm{mg} / \mathrm{kg}\end{array}$ & $94.5 \%$ & $103.3 \%$ & $108.1 \%$ & $93.8 \%$ & $\begin{array}{r}70-120 \% \\
70-120 \% \\
\end{array}$ \\
\hline
\end{tabular}

*Terms refer to SANTE/12682/2019

**MRL refers to the European Union through Regulation (EC) No. 396/2005 


\section{Sensitivity / Linearity}

The pesticide standard curve was created by analyzing the pesticide standard series using UPLC-MS/MS with optimized conditions. A linearity test is needed to determine the standard ability so that it can prove the existence of a linear relationship between analyte concentration and detector response (Dutta, D., Hingmire, S., dan Banerjee, K., 2020). The standard series used in this study was in the range of $0.05-0.100 \mathrm{mg} / \mathrm{L}$. From each standard curve, the coefficient of determination $\left(\mathrm{r}^{2}\right)$ was 0.9987 for carbaryl, 0.9950 for carbofuran, 0.9983 for dimethoate, and 0.9988 for acetate. The value of the coefficient of determination was more than or equal to 0.995 (Eurachem. 1998) so that it can be concluded that the method in this study has good linearity. However, according to the SANTE/12682/2019 document, the coefficient of determination is not sufficient. It is necessary to calculate the response from each point on the standard series and calculate the percent value of the standard series residual (deviation from the recalculated concentration). It is to ensure that each point on the standard series does not deviate much from its true value. In this study, the percent residual value of each point of the four analytes gave a value of -9.5 to $18.5 \%$ where SANTE/12682/2019 requires the percent residual value to be less than $\pm 20 \%$. It means that this method meets the sensitivity or linearity parameters.

\section{Matrix Effect}

The matrix effect is an important parameter in method validation because the matrix will affect the test results. Chawla, et al. (2017) stated that the matrix effect is highly dependent on the nature of the commodity and the pesticide analyte. Nearly $60 \%$ of the 38 pesticide analytes showed a matrix effect value greater than $20 \%$ or less than $-20 \%$. It means that most of the pesticide analytes were strongly influenced by the character of the matrix commodity used especially this study that uses nutmeg as an example which has a high content of essential oils and other organic compounds. The calculation of the parameters of this matrix effect is determined by calculating the difference in the average response of the standard in the matrix and the solvent. In this study, the matrix effect values of each analyte were $13.87 \%$ for carbaryl, $15.89 \%$ for carbofuran, $-25.84 \%$ for acetate, and $-21.96 \%$ for dimethoate. It means that for the test method of this sample, the acetate analytes and dimethoate must use the standard in the matrix when making the standard series because they have a matrix effect value of more than $\pm 20 \%$.

\section{Ion Ratio}

The ion ratio is the value of the response ratio between the quantification ion and the confirmation ion. This parameter is needed to ensure that the peak response area between the quantification ion and the confirmation ion does not have much difference. It means that the two ions are confirmed to come from the same compound. According to the SANTE/12682/2019 document, the sample ion ratio must be within the range of $\pm 30 \%$ (70$130 \%$ ) of the average value of the ion ratio sample in one sequence. In this study, all analytes gave ion ratio values in the range of 75$125 \%$. It can be concluded that the method used in this study met the requirements.

\section{Retention Time}

The retention time parameter was calculated by comparing the difference in the average retention time value of five repetitions for the standard analyte in acetonitrile solvent with the average retention time value of the analyte buffer in the sample matrix. In this study, all analytes showed retention times that met the requirements because they were within the range of \pm 0.100 of the difference between the standard retention times in the solvent and matrix.

\section{Limit of Quantification (LoQ)}

The determination limit is the smallest concentration of analyte in the sample that still

\section{6}

Copyright @ 2021 WJC | ISSN 2621-5985 (online) | ISSN 2549-385X (print)

Volume 4, Issue 2, 2021 
meets the criteria for accuracy and thoroughness, and can be quantified with good accuracy and precision (Ekaputri, 2013). This determination limit value is calculated from the results of five repetitions at the desired concentration, which is ideal for the specified concentration to have a value smaller than the Maximum Residue Limit (MRL) of the analyte. The value for dimethoate analyte is set at 0.078 $\mathrm{mg} / \mathrm{kg}$ and the MRL for dimethoate is $5 \mathrm{mg} / \mathrm{kg}$. After validation of the method, the limit value was $0.068 \mathrm{mg} / \mathrm{kg}$ with a $10 \%$ RSD value and 77$97 \%$ recovery. For the acetate analyte, the value is set at $0.078 \mathrm{mg} / \mathrm{kg}$ and the MRL for the acetate is $0.2 \mathrm{mg} / \mathrm{kg}$. After validation, the limit value was $0.085 \mathrm{mg} / \mathrm{kg}$ with a \%RSD of $11 \%$ and a recovery value of $89-119 \%$. For carbofuran analytes, the value is set at $0.040 \mathrm{mg} / \mathrm{kg}$ with MRL for carbofuran being $0.050 \%$. After validation, the limit value was $0.042 \mathrm{mg} / \mathrm{kg}$ with a \%RSD of $16 \%$ and the recovery value was $74-$ $112 \%$. For the carbaryl analyte, the value is set at $0.025 \mathrm{mg} / \mathrm{kg}$ with the MRL for carbaryl being $0.05 \mathrm{mg} / \mathrm{mg}$. After validation, the limit value was $0.019 \mathrm{mg} / \mathrm{kg}$ with a \%RSD of $14 \%$ and a recovery value of $85-104 \%$. According to the SANTE/12682/2019 document, the determination limit parameter in this study is declared valid because it meets the criteria, namely the $\%$ RSD value is less than $20 \%$ and the percent recovery value is in the range of $70 \%$ $120 \%$.

\section{Specificity}

Specificity is needed to determine the ability of the extraction process, clean up, derivatization, separation method, and detection method to distinguish analytes and interferents from the presence or absence of peak analyte area in the nutmeg sample and the extracted material sample. In this study, the analyte of carbaryl, carbofuran, and acephate did not give a peak response to the analyte area. While for the analyte dimethoate, it gave a peak analyte area with a concentration value of $1.98 \%$ of the limit value of determination. Thus, this specificity parameter meets the criteria set by the SANTE/12682/2019 document, namely the concentration value must be less than $30 \%$ of the determination limit.

\section{Precision (Repeatability and Reproducibility)}

Precision is the closeness between the results of the analysis obtained by applying the procedure with predetermined conditions. This repeatability precision value is calculated from the standard deviation value against repetition at a value of 10 times the limit setting. While the reproducibility precision value is calculated using the same method but for reproducibility related to the application of the same method in different conditions, namely the analyst, time, or different place of analysis (Chawla. et al, 2017). From this research, all the RSD percent values of each analyte are less than $20 \%$. It means that this precision parameter meets the requirements in the SANTE/12682/2019 document.

\section{Trueness or Recovery}

Trueness or correct value is expressed as "bias" which is the closeness of the average value of a series of test results (average recovery) to the accepted criteria or true value. In this study, values of $0.075 \mathrm{mg} / \mathrm{kg}$ and 0.350 $\mathrm{mg} / \mathrm{kg}$ were used as the correct values for the calculation of recovery. Based on table 3, the entire percent recovery value of all analytes was in the range of $70-120 \%$. It means that this parameter meets the requirements in the SANTE/12682/2019 document.

\section{Conclusion}

The QuEChERS optimization method in this study can be used for extraction and cleanup of nutmeg samples for analysis of carbaryl, carbofuran, acetate, and dimethoate pesticide residues. It has met the criteria set out in all method validation parameters listed in the SANTE/12682/2019 document. 


\section{References}

Anastassiades. M. et al. (2003) 'Fast and easy multiresidue method employing acetonitrile extraction/partitioning and "dispersive solid-phase extraction" for the determination of pesticide residues in produce'. Journal of AOAC International. $86 . \quad$ pp. 412-431. DOI: $10.1093 /$ jaoac/86.2.412

Badan Standardisasi Nasional. (2017) SNI ISO/IEC 17025:2017 Persyaratan umum kompetensi laboratorium pengujian dan laboratorium kalibrasi. Jakarta: Badan Standardisasi Nasional.

Biziuk. M. and Stocka. J. (2015) 'Multiresidue Methods for Determination of Currently Used Pesticides in Fruits and Vegetables Using QuEChERS Technique'. International Journal of Environmental Science and Development. 6(1). pp. 18-22. DOI: 10.7763/IJESD.2015.V6.554

Boes. E. et al. (2015) 'Development of validated method using QuEChERS technique for organochlorine pesticide residues in vegetable'. Procedia Chemistry. 16. 229236.

https://doi.org/10.1016/j.proche.2015.1 2.052

Boneva. I.. Yaneva. S.. and Danalev. D. (2021) 'Development and validation of method for determination of organophosphorus pesticides traces in liver sample by GCMS/MS-ion trap'. Acta Chromatographica. 33(2). pp. 188-194. DOI: https://doi.org/10.1556/1326.2020.007 78

British Standard. (2018) 'Foods of Plant Origin. Multimethod for the Determination of Pesticide Residues Using GC- and LCBased Analysis Following Acetonitrile Extraction/partitioning and Clean-up by Dispersive SPE. Modular QuEChERSmethod (BS EN 15662:2018)'. BSI: Brussels.
Chawla. S. et al.. (2017) 'Evaluation of Matrix Effects in Multiresidue Analysis of Pesticide Residues in Vegetables and Spices by LC-MS/MS'. Journal of AOAC International. 100(3). pp. 616-623. DOI: $10.5740 /$ jaoacint.17-0048

Das. S. et al. (2020) 'Validation of a Multiresidue Method for the Analysis of 86 Multiclass Pesticides in Litchi Fruit by Gas Chromatography-Tandem Mass Spectrometry'. Journal of AOAC International. 103(1). hal. 46-54. https://doi.org/10.5740/jaoacint.190203

Dinar. L.. Suyantohadi. A.. dan Fajar. M.A. (2013) 'Kajian Standar Nasional Indonesia Biji Pala'. Jurnal Standardisasi. 15(2). 83 - 90. DOI: http://dx.doi.org/10.31153/js.v15i2 .111

Direktorat Jenderal Perkebunan. (2019) 'Statistik Perkebunan Indonesia. Pala'. Jakarta: Direktorat Jenderal Perkebunan Kementerian Pertanian.

Dutta. D.. Hingmire. S.. Banerjee. K. (2020) 'Multiresidue Analysis of Pesticides in Moringa Pods by GC-MS/MS and LCMS/MS'. Journal of AOAC International. 103(6). $\quad$ pp. 1486-1497. DOI: $10.1093 /$ jaoacint/qsaa053

Ekaputri. R.A. (2013) 'Validasi Analisis Residu Pestisida Karbaril. Klorpirifos. dan Dimetoat dalam Buah Menggunakan Metode QuEChERS dan LC-MS/MS'. Skripsi. Jakarta: Universitas Indonesia.

Eurachem. (1998) 'The fitness for purpose of analytical method: A laboratory guide to method validation and related topics.' Diakses tanggal 19 Maret 2021 dari: https://www.eurachem.org/images/stor ies/Guides/pdf/MV_guide_1998_EN.pdf

Ferronato. G. et al. (2018) 'Determination of organochlorine pesticides (OCPs) in breast milk from Rio Grande do Sul. Brazil. using a modified QuEChERS method and 
gas chromatography-negative chemical ionisation-mass spectrometry'. International Journal of Environmental Analytical Chemistry. 98(11). 1005-1016. DOI: 10.1080/03067319.2018.1518441

Fitriadi. B.R.. dan Putri. A.C. (2016) 'Penentuan Residu Pestisida Deltametrin dan $\lambda$ Sihalotrin pada Lada (Piper nigrum L.) Menggunakan Metode QuEChERS'. Indo. J. Chem. Sci.. 5(2). hal. 91-97. DOI 10.15294/IJCS.V5I2.8908

Fitriadi. B.R.. dan Putri. A.C. (2019) 'Dampak Aplikasi Pestisida Sipermetrin. Deltametrin. Klorpirifos dan $\lambda$-Sihalotrin Terhadap Kandungan Residu Pestisida pada Biji Kakao'. Jurnal Agrosains dan Teknologi.3(2). hal. 10-18. DOI: https://doi.org/10.24853/jat.4.1.10 $-18$

Harmoko. Kartasasmita. R.E.. and Tresnawati. A. (2015) 'QuEChERS Method for the Determination of Pesticide Residues in Indonesian Green Coffee Beans using Liquid Chromatography Tandem Mass Spectrometry'. J. Math. Fund. Sci.. 47(3). pp. 296-308.

https://doi.org/10.5614/j.math.fund.sci. 2015.47.3.7

Jahanmard. E.. Ansari. F.. and Feizi. M. (2016) 'Evaluation of QuEChERS sample preparation and GC mass spectrometry method for the determination of 15 pesticide residues in tomatoes used in salad production plants'. Iranian Journal of Public Health. 45(2). pp. 230-238.

Koçyiğit. H. and Sinanoğlu. F. (2020) 'Method validation for the analysis of pesticide residue in aqueous environment'. Environ Monit Assess. 192:567. pp. 1-13 DOI: $10.1007 / \mathrm{s} 10661-020-08523-8$

Machado. I.. et al. (2017) 'Determination of pesticide residues in globe artichoke leaves and fruitsby GC-MS and LC-MS/MS using the same QuEChERS procedure'.
Food Chemistry. 227. pp. 227- 236. DOI: $10.1016 /$ j.foodchem.2017.01.025

Mancha A.. and Fuentes J. (2008). Evaluation of the health beneficial properties of the aromatic ether Myristicin. a volatile oil derived from various plants sources. The University of Texas-Pan American 1201 W. University Drive Edinburg. Texas. diakses tanggal 22 September 2021 dari http://agrilifecdn.tamu.edu/phytochemic als/files/2011/03/Myristicin_Nov9_330P M.ppt

Mastovska. K.. and Lehotay. S.J.. 2004. 'Evaluation of Common Organic Solvents for Gas Chromatographic Analysis and Stability of Multiclass Pesticide Residues'. Journal of Chromatography A. 1040: 259272. doi: 10.1016/j.chroma.2004.04.017.

Paz. M. et al. (2017) 'Application of the QuEChERS method for the determination of organochlorine pesticide residues in Brazilian fruit pulps by GC-ECD'. $J$ of Environmental Science and Health. Part B. 52(1). pp. 48-58. https://doi.org/10.1080/03601234.2016 .1229450

Pesireron. M. et al. (2019) 'Perbaikan Teknik Pengendalian Hama dan Penyakit pada Perkebunan Pala Banda (Myristica Fragrants Houtt) di Maluku'. Jurnal Littri. 25(1). hal. $45 \quad$ - 58. DOI: http://dx.doi.org/10.21082/littri.v2 5n1.2019.45-58

SANTE. (2019) 'SANTE/12682/2019 Analytical Quality Control and Method Validation Procedures for Pesticide Residues Analysis in Food and Feed'. Diakses tanggal 9 Maret 2021 dari https://www.eurlpesticides.eu/userfiles/file/EurlALL/Aqc Guidance_SANTE_2019_12682.pdf.

SANTE. (2020) SANTE/2020/12830 'Guidance Document on Pesticide Analytical Methods for Risk Assessment and Postapproval Control and Monitoring 
B. R. Fitriadi

Purposes'. Diakses tanggal 19 September 2021 dari https://ec.europa.eu/food/system/files/ 2021-

02/pesticides_mrl_guidelines_202012830.pdf.

Zhang. Y. et al. (2016) 'Multiresidue determination of pyrethroid pesticide residues in pepper through a modified QuEChERS method and gas chromatography with electron capture detection'. Biomed. Chromatogr.. 30. pp. 142-148.

https://doi.org/10.1002/bmc.3528 